\title{
Media Scandals as Fake News is Dangerous for the National Security
}

\begin{abstract}
In a Requiem for Media Jean Baudrillard described the civil war in Timisoara, Romania, in 1989. He discovered that the war was to a large extent instigated by the mass media.

Nowadays, the media have the possibility to decontextualize events and objectify them by placing them in a different context, alongside other decontextualized events. This could be very dangerous and lead to serious national security problems. Media could provoke social turbulence and "real" crimes. My aim in this paper is to describe this problem and show possible solutions. While following the methodology adopted, I examine case studies and analyze specific historical events.
\end{abstract}

Key words: media war, artificial events, journalistic ethics, philosophy of sport

$I_{\mathrm{t} h \mathrm{e}}^{\mathrm{n}}$ his The Requiem for the Media, Jean Baudrillard, the famous French philosopher of the mid-20 ${ }^{\text {th }}$ c., described how the TV news programs had been able to create events that had nothing to do with reality but at the same time they had serious public implications. Baudrillard gave an example of the civil war in Romania (Baudrillard, 1995). In 1989, the media reported that peaceful civilians were killed in Timisoara. Television stations showed dead bodies in the streets, cameras exhibited horrified faces, screams, gunshots, and building walls were strewn with bullets. The whole world decided that another communist dictator became crazy and started killing his rebellious population. Nicolae Ceausescu, the then leader of communist Romania, together with his wife, were shot without trial and sentence. However, this was accepted by journalists as a logical consequence of the civil war in Romania. In the end, it turned out that dead bodies in the streets of Timisoara had been deliberately removed from the local morgue and a very big part of the civil war was actually artificially created by a few reporters. This was followed by a number of similar cases, and Jean Baudrillard concluded that the society had been subordinated to media speculation and events had been taken out of context to show a desired fake reality (Baudrillard, 1995).

With the rise of the Internet and social media, the issue of information validity has become even more relevant. After the Arab Spring, it turned out that the Internet, virtual groups and social networks were able to take down dictatorial regimes, mobilize groups of people and encourage actions. However, crowds, spontaneously gathered through the social media, actually took over state's functions in their own hands, and it was serious threat to national security. Nowadays, Bulgarian state institutions suffer of mass distrust. Very often, the distrust is fueled by the media. Journalists fail to be objective and very often prioritize political and economic. According to Raicheva and Peicheva, the political environment in Bulgaria is characterized by almost permanent merger of political entities which increasingly use populist approaches, styles and rhetoric. The 
populist phraseology is transmitted to audiences mainly through the media. It has to be noted that during the period of democratization since 1989, pre-election campaigns have been developing in parallel to demonopolization, liberalization and transformation of the media system. Deregulation of the radio and TV broadcasting sector dragged on, giving way to the development of two mutually bound processes, namely politicization of the media and mediatization of politics (Raicheva, Peicheva, 2017). In other words, the state has only symbolic regulation over the media. And even the public media often resort to populism to impose certain views of the party in power or the media tycoon.

With the rise of the network society, according to the media analyst Ivan Krastev, the Bulgarian society is entering a new kind of Middle Ages, in the sense of the Dark Ages, in which people are more inclined to believe in virtual images from the TV screen rather than national authorities. For example, TV shows present litigations, doctors healing people through the screen etc. Bulgarians, according to Krastev, even when they get ill, prefer to check their symptoms on Google rather than go to their GPs (Krastev, 2005).

The situation in Bulgaria is reflecting a negative global trend. Moreover, according to Atanas Jdrebev, despite of the "blind trust" contemporary Bulgarian mass media are in a symbiosis with the political populism which has the following characteristics: antielitism - criticism of the dominant political elites as corrupt and their opposition to the ordinary people; anti-partyism - opposing traditional parties as separating the people and hindering the materialization of their common will; anti-institutionalism - denying the role of political institutions to make legitimate political decisions and represent the common will of the people; anti-democracy - non-compliance with principles of representative democracy and their methodical undermining; anti-constitutionalism - opposing the principles of a constitutional order; anti-pluralism - rejection of principles of political pluralism and their opposition to the general will of the people; demagogy - populists language that people want to hear; lack of core values, collaboration of populism with left and right ideologies; manipulating public dissatisfaction in situations of unsatisfied social and political demands; emergence of crisis in the legitimacy of the political system; plebiscitary direction - populists insist on frequent referendums; a charismatic leader who catalyzes populist mobilization; rejecting the role of institutions as mediators between the populist leader and the people; using resources of media democracy for direct and immediate communication between the leader and the people; opposition to ethnic minorities, immigrants and foreigners (Jdrebev, 2016).

These characteristics of the contemporary Bulgarian society and attitudes that mass media created are particularly visible in sports. The analysis of various sporting events and their coverage by the media clearly show problems described above and highlight the real threat to national security. As we can see, sport journalism and sport media can be very influential, especially when people watch sports, as they are less selective about political messages and more open to manipulation. At the same time, the media can create virtual crises (wars, scandals, provocations, etc.), and because of media's desire to raise their ratings, or to interact with political populism, they create serious problems for national security.

For instance, rejection of the role of national institutions is in itself a threat to national security. It is particularly interesting how sport has been used to inspire certain negative 
social attitudes, such as racism, homophobia, and how hooliganism can spill from a stadium to become a civil war (Mileva, 2014). Moreover, the yellow media also use sport to provoke a negative attitude towards sport: they take sport events out of their context and present them in a provocative manner to shock people. For better clarity, let us address a few specific and quite illustrative cases, such as soccer hooliganism, and sex and doping scandals involving athletes. These case studies cover specific sports scandals and fake news about sport events and athletes. All those incorrect representations introduce distrust to sport as the institution and athletes as public figures. Since sport has become an element of state's national politics, its negative image leads to distrust and the lack of respect for the state.

\section{Scandal Type One: Football/Soccer hooliganism}

\section{Dinamo Zagreb - Red Star (1990)}

On 13 May 1990, Dinamo Zagreb played a match against Red Star in the Yugoslav League. Throughout the day, Croatian TV channels showed how Serbian Red Star supporters stormed in Zagreb. Interestingly, although the police had the opportunity to stop fanatic supporter, the authorities let havoc happening on the streets of Zagreb. At the same time, instead of singing songs supporting their favorite team, Red Star football fans were chanting against Franjo Tudjman, the Croatia's newly elected president. In these circumstances, an hour before the match in the center of Zagreb, a large group of Bed Boy Blue - the Dinamo Zagreb fans gathered and publicly declared that they were "fed up" by Serbian fans. The police remained indifferent, the whole event was broadcast on Serbian and Croatian TV channels, and people from both countries became really angry at each other.

The match was not canceled despite the fact that its beginning was marked by flares flying between ultras groups and a Dynamo's fan was kicked by the Croatian captain Zvonimir Boban. Ultras started to fight with each other and the police as well. Complete chaos spread in the stadium. The match was a sparkle that ignited the already tangible conflict and opened hatred between Serbs and Croats. Several months later, the civil war began. The war cost millions of people's lives.

If at an early stage of the conflict the media had appealed for peace and understanding instead of showing the vandalism of the ultras, perhaps there would have been no civil war but a peaceful resolution of the conflict. Of course, we can never be sure, but for certain the match could have ended in a much more civilized way.

Football hooliganism is not only a threat to order in a city, it is also a threat to national security and the state's international image. A stadium is a venue where all problems within a community can crystallize and become more visible, especially with the help of mass media. Such conflicts can have a purifying function for the community, since they can highlight a hidden problem. Another example of the above is the football match Bulgaria-England held on 14.10.2019. 


\section{Bulgaria-England 0-6 (14.10.2019)}

What was striking about the match was not the huge 0-6 loss of the Bulgarian national team, but the ensuing racist scandal. The match was interrupted three times because of racist cheering by Bulgarian ultras showing Nazi greetings and imitating monkey sounds whenever a black footballer took over the ball. Although all TV cameras and photographs showed the situation, Krasimir Balakov, the coach of the national team, claimed he had not noticed any such behavior. The obscene behavior was closely observed by the English media. One of the headlines in The Guardian was England's Vile and Disturbing Night in Sofia will live long in sporting infamy. ${ }^{1}$ Unfortunately, instead of focusing on racism in Bulgaria, commercial media, eager to raise their ratings, printed such titles as Lions - 6/Animals - 0 ("The Sun", 15.10.2019) which also showed the racist attitude of the English media. This led to some tensions between the two countries, nationalistic sentiments in both countries escalated, and instead of focusing on the main issue, the tensions deepened.

\section{Scandal Type Two: Doping}

According to Baudrillard, public scandals result from the desire of media officials to find flaws in the status quo, assure the public that perpetrators have been captured and good has prevailed. A similar media practice could be observed during the Watergate scandal when President Nixon was impeached because he had tapped his political opponents. The news spread around the world and the public could have believed that evil was punished and good, democracy and equality, triumphed. However, the issue of people being tapped is still valid today. It has not been resolved, and it is the problem with scandals concerning our distinguished athletes and politicians. In this way, a "scape goat" is found, the person is punished, but the problem remains. At the same time, public figures can easily be smeared. When authorities are not strong enough to demythologize the media and misinformation, there is no opposition, and propaganda becomes more powerful than ever.

The first such case involves Ben Johnson, a famous Canadian athlete. He was a role model for adolescents. Growing up in a poor immigrant family, he became the symbol of what a person could do with his willpower and hard training. At the 1988 Seoul Olympics, he was caught doping and "lynched" by the media, who did not spare him racist comments.

And yet, this scandal failed to put an end to doping in elite sports. Such scandals did not answer the question of why doping was needed in elite sports. Investigative journalism, in this period, shifted to yellow journalism, over-the-top news, and disguised personalities of indisputably top athletes.

The second case involving an athlete of this caliber is related to Lance Armstrong, who literally became one of the most beloved athletes of the United State until the date he was caught doping. In 2011, he was ranked the most beloved athlete in the United

${ }^{1} \mathrm{https} / /$ www.theguardian.com/football/2019/oct/14/six-minutes-added-time-racism-england-bulgaria-euro-2020. 
States by the Forbes. The following year, he was caught on dope and became the most hated athlete in the same ranking. All media gave a wide coverage of the Armstrong scandal, from Oprah Winfrey to Eurosport. Armstrong failed, although he tried to draw attention to the fact that doping was a part of the elite sport and it was difficult to discuss professional sports without any use of illicit substances.

Doping is not a problem of an individual athlete, it is a problem of professional sports. The ultimate goal of winning, as Prodanov (Prodanov, 2014) pointed out, the desire of a quick and spectacular victory, and the pressure to break records have encouraged athletes to take illicit drugs. In many instances, they do not even know that they take. Doping is sometimes vague that it gives rise to paradoxes, and this is how people perceive the problem. An example of the above is Marta Sharapova, the famous tennis player of Russian descent. After she was caught doping, her sponsors and the public immediately withdrew their support. This, however, did not happen to Andre Agassi, who was caught on methamphetamines in 1997. Another example is sprinter Justin Gatlin who still enjoys public and sponsor's affection, despite of being caught doping twice. The media, however, inflate cases in a completely different way and in a sense determine public discontent. It turned out that the Sharapova's doping scandal coincided with the attempt to discourage sponsors of aging Sharapova who had not won any major tournament in two years. Thus, the main reason was Sharapova's age rather than the use of illicit substances. Moreover, she was of Russian origin. It was also very difficult to prove that doping was not a part of the state policy. In the Eastern bloc countries, in Bulgaria in particular, especially during the Cold War, athletes were forced to take illicit substances. The logic is simple, an athlete is doped, he/she wins, and the glory is for their country. Probably at the 2020 Olympic Games in Tokyo, the Russians will not compete under their own flag. The problem of doping remains unsolved and the state image and credibility suffer.

\section{Scandal Type Three: Sex scandals}

Undoubtedly, the biggest and pointless scandal, entirely product of the media, was the one involving Tiger Woods. The famous golfer divorced the Swedish model Erin Nordegern in 2004. The reason for it was a sex scandal. He was a symbol of how a boy from the ghetto, a representative of the minority group, could become a champion in golf, the game of the rich. Moreover, in 2005-2015, he had earned US\$ 845 million, which put him in the forefront of the best-paid athletes. In public space, however, the focus was on his out-of-wedlock relationships, not on his skills. Rankings of Tiger Woods' Hottest Mistresses appeared at every website. The media called him a racist because his lovers were only white women, and instead of his lightning strike, the public interest was channeled to his personal life.

There are thousands of such examples in Bulgaria. People are informed about athletes' feats in night clubs, rather their achievements in sports. This is an example of disinformation, since it does not allow to develop an objective assessment of an athlete, his/her qualities and skills. By focusing on weaknesses, we deprive famous athletes of their authority and appeal. Moreover, one of the characteristics of totalitarian regimes is 
precisely the destruction of the image of authoritative persons. Nowadays, athletes seem to be serving their sponsors, and when they are no longer needed, the sponsor quickly gets rid of them, whether it is because of their age or "immoral" behavior.

\section{Conclusions and recommendations}

These examples are indicative of how the media create their own reality, which can be completely taken out of context and has nothing to do with the real situation. However, people fully accept what they hear and see in the media, and such media behavior inspire distrust to institutions and authorities. When there are no institutions, authoritative personalities, and people to be followed as examples, images created by the media become the only reality, reality which is often designed solely to misinform.

\section{There are three main ways we can deal with fake news}

Firstly, it is education, especially the one offered by institutions educating journalists, which need to put more stress on ethical and philosophical education. These subjects develop students' critical thinking and teach moral values. In is important because a good journalist has to be a good citizen of high moral standards first and then a professional.

Secondly, all educational institutions should incorporate news literacy education. News literacy gives practical knowledge of how to distinguish reliable information from fake and trending news. Such knowledge can be used as a tool in any situation. By following simple rules, anyone can verify the accuracy of information, check if an article is signed, whether different viewpoints are reflected, and whether the speaker/writer is a specialist in the field. By promoting relevant attitudes, News Literacy also helps to verify credibility of everything people see on television and always question information provided and to subject it to news literacy methods.

Thirdly, we can resort to independent, non-profit and crowdfunding media. According to Pierre Bourdieu, the new media should be a type of a "city of knowledge" - media in which only experts can express opinions, free from pressure of advertisers and not limited by time and place as traditional media, including television and newspapers (Bourdieu, 1999). Web-based media, blogs and vlogs are becoming increasingly popular, but their quality remains an issue. This is where we can use news literacy to verify information disseminated.

\section{Bibliography}

Bourdieu P. (1999), On Television, The New Press.

Baudrillard J. (1995), Requiem of Media. The illusion of the end or strike of events, Criticism and Humanism Publish House, Sofia (in Bulgarian).

Jdrebev A. (July 23, 2016), The Bulgarian Academic Debate on Populism, "Rhetoric and Communications", no. 23, http://rhetoric.bg/, 18.06.2017 (in Bulgarian).

Krastev I. (2001), Under the Line, Torch (in Bulgarian). 
Lions - 6/Animals - 0, “The Sun", 15.10.2019.

McLuhan M. (1964), Understanding Media: The Extension of Man, Routledge.

Mileva E. (2014), Sporting as a Prevention of Football Hooliganism, "Sport \& Science Magazine", Issue 5, pp. 48-54 (in Bulgarian).

Prodanov J. (2014), Philosophical Essays on Sport, NSA Press (in Bulgarian).

Raicheva L., Peicheva D. (2017), Populism in Bulgaria Between Politicization of Media and Mediatization of Politics, "Mediatization Studies", no. 1, DOI: 10.17951/ms/2017.1.1.69.

\section{Skandale medialne jako „Fake News” są zagrożeniem dla bezpieczeństwa narodowego}

\section{Streszczenie}

W Requiem dla Mediów Jean Baudrillard opisał wojnę domową w rumuńskiej Timisoarze, która odbyła się w 1989 roku. Odkrył on, iż wojna ta została w znacznej mierze zainicjowana przez media masowe. Obecnie media mają możliwość dekontekstualizacji wydarzeń oraz ich obiektywizacji przez umieszczenie w innym kontekście obok innych zdekontekstualizowanych wydarzeń. Stanowi to istotne zagrożenie i może prowadzić do istotnych problemów z punktu widzenia bezpieczeństwa narodowego. Media mogą prowokować turbulencje społeczne i ,prawdziwe” przestępstwa. Moim celem w tym artykule jest opisanie tego problemu i ukazanie możliwych rozwiązań. Stosując przyjętą metodologię, badam studia przypadków i analizuję wydarzenia historyczne.

Słowa kluczowe: wojna medialna, sztuczne wydarzenia, etyka dziennikarska, filozofia sportu 
